\title{
Constrained Corticotropin Releasing Factor Antagonists (Astressin Analogues) with Long Duration of Action in the Rat ${ }^{\dagger}$
}

\author{
J ean E. Rivier,* Dean A. Kirby, Sabine L. Lahrichi, Anne Corrigan, Wylie W. Vale, and Catherine L. Rivier \\ The Clayton Foundation Laboratories for Peptide Biology, The Salk Institute for Biological Studies, \\ 10010 North Torrey Pines Road, La J olla, California 92037
}

Received April 29, 1999

In an earlier report we identified specific modifications and substitutions of corticotropin releasing factor (CRF) that led to the discovery of antagonists with extended duration of action as compared to that of astressin $\left\{\mathrm{cyclo}(30-33)\left[\mathrm{DPhe}^{12}, \mathrm{Nle}^{21}, \mathrm{Glu}^{30}, \mathrm{Lys}^{33}, \mathrm{Nle}^{38}\right] \mathrm{hCRF}{ }_{(12-41)}\right\}$. These additional modifications included elongation of the peptide chain by three residues at the $\mathrm{N}$-terminus, its acetylation, and the $\left[\mathrm{C} \alpha \mathrm{MeLeu}^{27}\right]$ substitution to yield cyclo(30-33)[DPhe ${ }^{12}$, $\mathrm{Nle}^{21}, \mathrm{C} \alpha \mathrm{MeLeu}^{27}, \mathrm{Glu}^{30}, \mathrm{Lys}^{33}, \mathrm{Nle}^{38} \mathrm{AAC}^{-h C R F}{ }_{(9-41)}$, which was found to be longer acting than astressin (Rivier, J.; et al. J. Med. Chem. 1998, 41, 5012-5019). To further increase the efficiency (potency, duration of action, and bioavailability) of this family of antagonists, we introduced two or more CaMe-leucine residues at positions shown in earlier studies to be favorable (Hernandez, J.-F.; et al. J. Med. Chem. 1993, 36, 2860-2867). Whereas the introduction of $\mathrm{C} \alpha \mathrm{Me}$-leucine residues at positions 27 and either 18 (11), 37 (17), or 40 (19) resulted in dramatic increases in duration of inhibitory action in the adrenalectomized (adx) rat after intravenous injection, the same substitution at positions 27 and either $15(\mathbf{7}, \mathbf{8}), 17$ (9), $19(\mathbf{1 2}, \mathbf{1 3})$, or 41 (20) led to short acting analogues. Other substitutions by C $\alpha$ MeLeu at positions 27 and either 10 (4), 13 (5), 14 (6), 21 (14), 24 (15), 36 (16), or 38 (18) yiel ded analogues with duration of action intermediate between those mentioned above. Cyclo(30-33)[DPhe12, $\mathrm{NIe}^{21}, \mathrm{C} \alpha \mathrm{MeLeu}^{27}, \mathrm{Glu}^{30}, \mathrm{Lys}^{33}, \mathrm{Nle}^{38}, \mathrm{C} \alpha \mathrm{MeLeu}^{40} \mathrm{ACC}^{2} \mathrm{hCRF}\left({ }_{(9-41)}\right.$ (astressin B, 19) was one of the most efficacious analogues of this series ( $>4 \mathrm{~h}$ inhibition of ACTH secretion at $25 \mu \mathrm{g} / \mathrm{adx}$ rat). It was found to be even longer acting via subcutaneous administration in either an aqueous ( $>24 \mathrm{~h}$ inhibition of ACTH secretion at $100 \mu \mathrm{g} / \mathrm{adx}$ rat) or lipid milieu (DMSO/peanut oil, $>24$ $\mathrm{h}$ inhibition of ACTH secretion at $30 \mu \mathrm{g} / \mathrm{adx}$ rat) than after intravenous administration $(<12$ $\mathrm{h}$ inhibition of ACTH secretion at $100 \mu \mathrm{g} / \mathrm{adx}$ rat). We concluded that $\mathrm{C} \alpha$-methylation at some positions may favor a bioactive conformation while also preventing degradation and/or elimination, resulting in significant extension of duration of action.

\section{Introduction}

The existence of corticotropin releasing factor (CRF) was first proposed in 1955 by Guillemin and Rosenberg ${ }^{3}$ and Saffran and Schally. ${ }^{4}$ I nitially isolated from ovine hypothalamus and characterized as a 41 amino acid peptide in $1981,{ }^{5}$ CRF was subsequently characterized from rat hypothalami, ${ }^{6}$ and the identical structure was deduced for human CRF on the basis of the CDNA sequence of the human CRF precursor gene. ${ }^{7}$ Presently, more than a dozen members of the CRF family (induding sauvagine, urotensins, and urocortins) have been

\footnotetext{
${ }^{\dagger}$ Abbreviations. IUPAC rules are used for nomenclature of peptides including one-letter codes for amino acids. The foll lowing abbreviations are also used: Ac, acetyl; ACTH, adrenocorticotropin hormone; astressin, Cyclo(30-33) [DPhe $\left.{ }^{12}, \mathrm{Nle}^{21,38}, \mathrm{Glu}^{30}, \mathrm{Lys}^{33}\right] \mathrm{hCRF}_{(12-41)}$; Boc, tertbutyloxycarbonyl; BOP, benzotriazolyloxy-tris(dimethylamino)phosphonium hexafluorophosphate; BSA, bovine serum albumin; CRF, corticotropin releasing factor (o = ovine, $h=$ human); CRFR, CRF receptor; CZE, capillary zone el ectrophoresis; DCM, dichloromethane; DIC, diisopropylcarbodiimide; DMF, dimethylformamide; F moc, 9-fluorenylmethoxycarbonyl; HBTU, O-(benzotriazol-1-yl)-N, N, $\mathrm{N}^{\prime}, \mathrm{N}^{\prime}$-'tetramethyluronium hexafluorophosphate; $\mathrm{HF}$, hydrogen fluoride; IA, intrinsic activity; MBHA, 4-methyl benzhydrylamine; NMP, N-methylpyrrolidone; OFm, O-fluorenylmethyl; SAR, structure-activity relationships; TBTU, O-(benzotriazol-1-yl)- $\mathrm{N}, \mathrm{N}, \mathrm{N}^{\prime}, \mathrm{N}^{\prime}$-tetramethyluronium tetrafluoroborate; TEAP 2.25, 4.5, 6.5, triethylammonium phosphate $\mathrm{pH} 2.25,4.5,6.5$; TFA, trifluoroacetic acid.

* Corresponding author. Tel: (619) 453-4100. Fax: (619) 552-1546. E-mail: jrivier@salk.edu.
}

described. CRF plays a major role in the maintenance or restoration of homeostasis by stimulating the activity of the hypothalamic-pituitary-adrenal (HPA) axis. ${ }^{8}$ It also acts within the brain to control immune, ${ }^{9}$ reproductive, ${ }^{10}$ and cardiovascular functions, ${ }^{11,12}$ as well as catecholamine release, ${ }^{13}$ drug withdrawal, ${ }^{14,15}$ behavior , ${ }^{16}$ mood, ${ }^{17}$ and anxiety. ${ }^{18,19}$ CRF also acts through the release of adrenal corticosteroids to alter immune parameters ${ }^{20}$ and to participate in the regulation of carbohydrate metabol ism by enhancing the availability of glucose [reviewed in Dallman et al.21]. Finally, the broad central and peripheral distribution of the peptide and its two classes of seven-transmembrane-helix Gprotein-coupled CRF receptors ${ }^{22-28}$ supports the notion that CRF is also an important local neurotransmitter within the central nervous and immune systems among others.

CRF immunoreactivity and mRNA are found in cell bodies throughout the brain. CRF exerts a number of cellular actions in the brain; it modifies the production of CAMP, regulates the secretion of monoamines and neuropeptides, and modulates membrane potentials and ion currents. When CRF is injected into the brain, the sympathetic nervous system is activated while the parasympathetic nervous system is suppressed, resulting in an increase in heart rate and blood pressure, an 
inhibition of digestive functions (upper gastrointestinal tract), and activation of the lower gastrointestinal tract (elimination). ${ }^{29}$ After intracerebroventricular administration of low doses, CRF stimulates arousal and increases performance in various learning and memory tests. At higher doses, CRF increases emotionality, induces fear, anxiety, and depression-like symptoms in some species. Antagonists, on the other hand, would have anxiolytic effects in that paradigm. F or this reason, a number of pharmaceutical companies have concentrated their efforts toward the identification of nonpeptide ligands to the CRF receptors that would be orally active and that would cross the blood brain barrier (BBB). Such non-peptide ligands for CRF- $R_{1}$ have been described. ${ }^{30-37}$ The fact that they cross the BBB, however, limits their use as investigative tools to dissect the role of CRF in either the CNS or the periphery, as they will be distributed in both compartments.

Additionally, peripheral administration of CRF delays gastric emptying of a non-nutrient liquid meal when injected peripherally in conscious rats, mice, and dogs. $^{38-45}$ The inhibition of gastric motor function induced by CRF is mediated by activation of peripheral CRF receptors as shown by the complete inhibition of CRF's inhibitory action by pretreatment with the peptides CRF antagonist $\alpha$-helical $\mathrm{CRF}_{(9-41)}$, [D-Phe ${ }^{12}$, $\left.\mathrm{Nle}^{21,38}\right]$ CRF $(12-41)$, and astressin. ${ }^{38,46,47}$ All of these CRF antagonists injected intravenously also prevent gastric stasis induced by abdominal surgery in rats. $38,46,47$ Ther efore, the devel opment of long acting CRF antagonists will be of rel evance in the context of postoperative gastric ileus.

Our interest in understanding the structure-activity relationships (SAR) of CRF stems from the hypothesis that conditions characterized by an imbalance of CRF might be all eviated by the administration of long acting CRF agonists or antagonists. Except for one report describing the use of $\alpha$-hel-CRF in humans, a weak and safe antagonist, ${ }^{48}$ CRF peptide antagonists described so far have been too weak to warrant further clinical investigations. Although we have reported that astressin is longer acting than any earlier CRF antagonists, its duration of action is still too short to warrant its use in chronic studies that would lead to an understanding of the tonic role of peripheral CRF. Here we describe studies that led to the discovery of several CRF peptide antagonists that, due to their high potency, long duration of action, and the unlikelihood that they would cross the BBB, could also be promising clinical candidates to manage a number of conditions thought to be associated with excessive and sustained cortisol secretion. High levels of cortisol have been associated with depression, hypertension, osteoporosis, immunosuppression, and the entire spectrum of metabolic syndrome $X$ (see Chrousos and Gold and references therein ${ }^{49}$ ). A potent peptide antagonist that would cross the BBB under certain modes of administration (such as intranasal), but not under other peripheral modalities, would al so be very useful to manage conditions resulting from central, hypothalamic, and peripheral hypersecretion of CRF. Such states include mental (depression), immune (rheumatoid arthritis, thyroiditis, ulcerative colitis, immune uveitis), and gastrointestinal (ileus, irritable bowel syndrome, etc.) dysfunctions. Finally, excess CRF has al so been implicated in inducing premature labor. ${ }^{50}$

In summary, CRF is considered to stimulate many of the functions that help the organism survive (such as locomotor activity and catecholamine release) while inhibiting those that might interfere with an effective stress response. We describe here additional modifications of $\mathrm{Cyclo}(30-33)\left[\mathrm{DPhe}^{12}, \mathrm{Nle}^{21}, \mathrm{C} \alpha \mathrm{MeLeu}^{27}, \mathrm{Glu}^{30}\right.$, $\mathrm{DHis}^{32}, \mathrm{Lys}^{33}, \mathrm{Nle}^{38} \mathrm{JAc} \mathrm{hCRF}{ }_{(9-41)^{1}}$ that led to CRF antagonists with such long duration of action that they may be useful and practical for chronic in vivo studies.

\section{Results and Discussion}

All analogues shown in Table 1 were synthesized either manually or automatically on a methylbenzhydrylamine (MBHA) resin using the Boc strategy with orthogonal protection of the side chains of the lysine ( $\mathrm{Fmoc}$ ) and glutamic acid (OF $\mathrm{m}$ ) residues to be cyclized. ${ }^{51-54}$ Main chain assembly was mediated in most cases by diisopropylcarbodiimide (DIC). The sol id phase assembly of the C $\alpha$-substituted CRF analogues presented some difficulties that were remedied using a 1:1 mixture of BOP/HOBt (pH 9-10, 2 h) and a 3.5-fold excess of Boc-C $\alpha$-methyl leucine, ${ }^{2,55}$ In case of incomplete couplings, monitored by Kaiser's ninhydrin test, 56 couplings were repeated followed by acetylation. Cleavage of the $\mathrm{Fmoc}$ and OFm protecting groups was achieved using piperidine after complete assembly of the peptide resin; lactam formation was mediated by TBTU or BOP. ${ }^{52}$ The peptide resins were treated with $\mathrm{HF}$ to liberate the fully deblocked crude peptides which were purified using reverse phase HPLC and three different buffer systems in the following order: TEAP 2.25, TEAP 4.5 or TEAP 6.5 , and $0.1 \%$ TFA. $1,52,54,57-59$ The highly purified final products were isolated as the trifluoroacetate salts and characterized using HPLC, CZE, and liquid secondary ionization mass spectrometry (LSIMS) (Table 1). The measured masses obtained using LSIMS were within $100 \mathrm{ppm}$ of those calculated for the protonated molecule ions. The compounds were tested for their ability to antagonize CRF-induced release of ACTH by rat pituitary cells in culture. ${ }^{5,60,61}$ Duration of action was assessed in the adrenalectomized rat according to published procedures. ${ }^{60}$

In this article we describe SAR studies designed to identify additional residues to those shown earlier to increase the duration of action of astressin analogues in the adrenalectomized ( $\mathrm{adx})$ rat. The approach consisted of introducing $\mathrm{C} \alpha \mathrm{MeL}$ eu residues in addition to that in position 27 (2) which had al ready been found to be favorable. ${ }^{1}$ The rationale for such substitutions was that $\mathrm{C} \alpha \mathrm{MeL}$ eu is compatible with retention of $\alpha$-helical structure and is likely to be more resistant to the action of endopeptidases than Leu. Positions that were selected for such substitutions included those positions where leucine is found in native members of the CRF family. In CRF, these include positions 10,14, 15, 19, and 37, in addition to position 27 that was shown to be a favorable substitution. ${ }^{1}$ Additionally, Leu is a native substitution in the 40 amino acid human urocortin at positions $13,14,17,18$, and 20 , which translates into positions 14, 15, 18, 19, and 21 in the 41 amino acid hCRF. In the 40 amino acid sauvagine, leucine exists at positions $9,11,13,14,35,36$, and 37, and corresponds 
Table 1

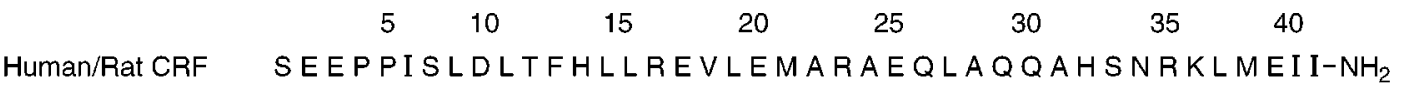

\begin{tabular}{|c|c|c|c|c|c|c|c|c|c|}
\hline \multirow{2}{*}{$\begin{array}{l}\text { ID } \\
\text { no. }\end{array}$} & \multirow[b]{2}{*}{ CRF antagonists } & \multirow[b]{2}{*}{ HPLCa } & \multirow[b]{2}{*}{$C Z E^{b}$} & \multicolumn{2}{|c|}{ MS (mono) } & \multirow{2}{*}{$\begin{array}{c}\text { rel. } \\
\text { potencies } \\
\text { in vitro }\end{array}$} & \multirow[b]{2}{*}{$\mathrm{IA}^{\mathrm{e}}$} & \multirow{2}{*}{$\begin{array}{l}\text { dur. of } \\
\text { action }\end{array}$} & \multirow[b]{2}{*}{ refs } \\
\hline & & & & calcd & found & & & & \\
\hline 1 & $\begin{array}{l}\text { cyclo(30-33)[DPhe }{ }^{12}, \mathrm{Nle}^{21}, \mathrm{Glu}^{30}, \mathrm{DHis}^{32} \\
\left.\text { Lys }^{33}, \mathrm{Nle}^{38}\right] \mathrm{hCRF}_{(12-41)}\end{array}$ & 97 & $>97$ & 3562.05 & 3562.4 & 1.00 & 25 & SA & 59 \\
\hline 2 & $\begin{array}{l}\text { cyclo(30-33)[DPhe }{ }^{12}, \mathrm{Nle}^{21}, \mathrm{C} \alpha \mathrm{MeLeu}^{27}, \mathrm{Glu}^{30}, \mathrm{Lys}^{33}, \\
\mathrm{Nle}^{38} \mathrm{hCRF}_{(9-41)}\end{array}$ & 93 & 92 & 3947.23 & 3947.9 & $\begin{array}{l}1.7(0.6-4.2) \\
0.67(0.41-1.1)\end{array}$ & 12 & MA & 1 \\
\hline 3 & $\begin{array}{l}\text { cyclo(30-33)[DPhe }{ }^{12}, \mathrm{Nle}^{21}, \mathrm{C} \alpha \mathrm{MeLeu}^{27}, \mathrm{Glu}^{30}, \mathrm{DHis}^{32}, \\
\left.\text { Lys }^{33}, \mathrm{Nle}^{38}\right]_{\mathrm{Ac}-h C R F}{ }_{(9-41)}\end{array}$ & 100 & NA & 3947.23 & 3947.2 & $\begin{array}{l}3.9(2.1-7.5) \\
0.49(0.30-0.79)\end{array}$ & 23 & MA & 1 \\
\hline
\end{tabular}

\begin{tabular}{|c|c|c|c|c|c|c|c|c|}
\hline \multirow{2}{*}{$\begin{array}{l}\text { ID } \\
\text { no. }\end{array}$} & \multirow[b]{2}{*}{ with two C $\alpha$ MeLeu substitutions } & \multirow[b]{2}{*}{ HPLCa } & \multirow[b]{2}{*}{$C E^{b}$} & \multicolumn{2}{|c|}{ MS (mono) } & \multirow{2}{*}{$\begin{array}{l}\text { rel. } \\
\text { potencies } \\
\text { in vitro }\end{array}$} & \multirow[b]{2}{*}{$\mathrm{IA}^{\mathrm{e}}$} & \multirow{2}{*}{$\begin{array}{l}\text { dur. of } \\
\text { action }\end{array}$} \\
\hline & & & & calcd & found & & & \\
\hline 4 & $\begin{array}{l}\text { cyclo(30-33)[C } \alpha \mathrm{MeLeu}^{10}{ }^{10} \mathrm{DPhe}^{12}, \mathrm{Nle}^{21}, \mathrm{C} \alpha \mathrm{MeLeu}{ }^{27}, \mathrm{Glu}^{30}, \\
\left.\text { Lys }^{33}, \mathrm{Nle}^{38}\right] \mathrm{Ac}^{3} \mathrm{hCRF}(9-41)\end{array}$ & 94 & 97 & 3961.2 & 3961.3 & $0.18(0.07-0.41)$ & 34 & MA \\
\hline 5 & 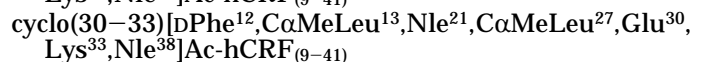 & 95 & 94 & 3937.3 & 3937.3 & $0.8(0.35-1.9)$ & 9 & MA \\
\hline 6 & 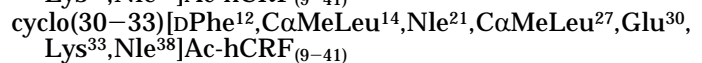 & 98 & 98 & 3961.2 & 3961.3 & $0.68(0.42-1.1)$ & 0 & MA \\
\hline 7 & 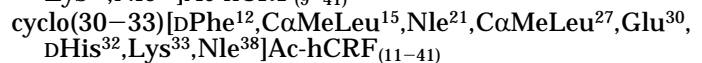 & 96 & 95 & 3733.14 & 3733.1 & $1.1(0.62-2.0)$ & 0 & SA \\
\hline 8 & 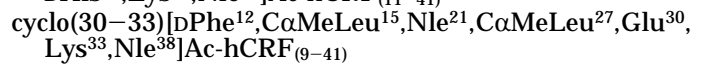 & 94 & 99 & 3961.2 & 3961.3 & $0.55(0.26-1.2)$ & 3 & SA \\
\hline 9 & $\begin{array}{l}\text { cyclo(30-33)[DPhe }{ }^{12}, C \alpha M e L e^{17}, \mathrm{Nle}^{21}, \mathrm{C} \alpha \mathrm{MeLeu}^{27}, \mathrm{Glu}^{30}, \\
\left.\text { Lys }^{33}, \mathrm{Nle}^{38}\right] \mathrm{Ac}-\mathrm{hCRF}(9-41)\end{array}$ & 83 & 79 & 3945.3 & 3945.3 & $0.10(0.03-0.26)$ & 0 & SA \\
\hline 10 & 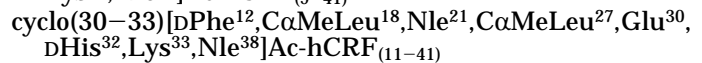 & 97 & 100 & 3747.15 & 3746.9 & $1.9(0.97-4.1)$ & 9 & MA \\
\hline 11 & 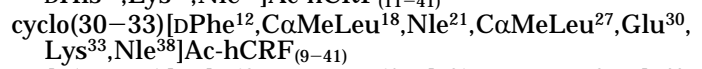 & 93 & 95 & 3975.3 & 3975.8 & $0.64(0.26-1.6)$ & 18 & LA \\
\hline 12 & $\begin{array}{l}\text { cyclo(30-33)[DPhe12, CaMeLeu }{ }^{19}, \mathrm{Nle}^{21}, \mathrm{C} \alpha \mathrm{MeLeu}^{27}, \mathrm{Glu}^{30}, \\
\left.\text { DHis }^{32}, \mathrm{Lys}^{33}, \mathrm{Nle}^{38}\right] \mathrm{Ac}-\mathrm{hCRF} \\
(11-41)\end{array}$ & 98 & 99 & 3733.14 & 3733.2 & $0.57(0.36-0.90)$ & 5 & SA \\
\hline 13 & 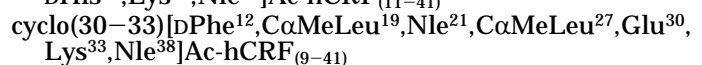 & 94 & 99 & 3961.2 & 3961.3 & $0.066(0.030-0.14)$ & 15 & SA \\
\hline 14 & $\begin{array}{l}\text { cyclo(30-33)[DPhe }^{12}, \mathrm{C}^{3} \mathrm{MeLeu}^{21,27}, \mathrm{Glu}^{30}, \mathrm{Lys}^{33} \\
\left.\mathrm{Nle}^{38}\right] \mathrm{Ac}-\mathrm{DCRF}_{(9-41)}\end{array}$ & 93 & 96 & 3961.25 & 3961.0 & $4.3(0.95-23)$ & 0 & MA \\
\hline 15 & $\begin{array}{l}\text { cyclo(30-33)[DPhe }{ }^{12}, \mathrm{Nle}^{21}, \mathrm{C} \alpha \mathrm{MeL} \mathrm{eu}^{24,27}, \mathrm{Glu}^{30}, \mathrm{Lys}^{33}, \\
\left.\mathrm{Nle}^{38}\right] \mathrm{Ac}-\mathrm{hCRF}(9-41)\end{array}$ & 98 & 97 & 4003.3 & 4003.3 & $0.77(0.29-2.0)$ & 0 & $\mathrm{MA}$ \\
\hline 16 & 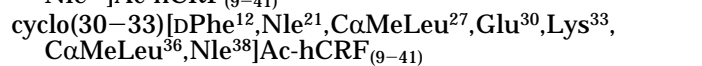 & 95 & 97 & 3946.24 & 3946.3 & $1.7(0.53-5.8)$ & 0 & MA \\
\hline 17 & 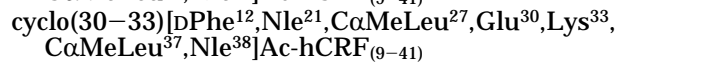 & 98 & 99 & 3961.2 & 3961.2 & $0.51(0.29-0.89)$ & 5 & LA \\
\hline 18 & $\begin{array}{l}\text { cyclo(30-33)[0Phe } 12, \mathrm{Nle}^{21}, \mathrm{C} \alpha \mathrm{MeLeu}^{27}, \mathrm{Glu}^{30}, \mathrm{Lys}^{33}, \\
\left.\text { C } \alpha \mathrm{MeLeu}^{38}\right] \mathrm{Ac}^{3} \mathrm{hCRF}_{(9-41)}\end{array}$ & 99 & 97 & 3961.2 & 3961.3 & $0.27(0.16-0.45)$ & & \\
\hline 19 & 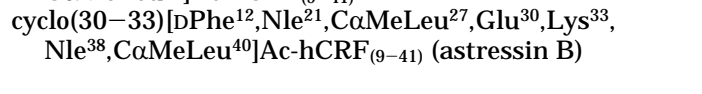 & 98 & 99 & 3961.2 & 3961.3 & $\begin{array}{l}0.45(0.25-0.80) \\
1.0(0.47-2.3) \\
1.1(0.50-2.5)\end{array}$ & $\begin{array}{r}13 \\
0 \\
12\end{array}$ & LA \\
\hline 20 & $\begin{array}{l}\text { cyclo(30-33)[DPhe }{ }^{12}, \mathrm{Nle}^{21}, \mathrm{C} \alpha M \text { Me eu }{ }^{27}, \mathrm{Glu}^{30}, \mathrm{Lys}^{33}, \\
\left.\mathrm{Nle}^{38}, \mathrm{C} \alpha \mathrm{MeLeu}{ }^{41}\right] \mathrm{Ac}-\mathrm{hCRF}(9-41)\end{array}$ & 96 & 99 & 3961.2 & 3961.3 & $\begin{array}{l}0.020(0.009-0.040) \\
0.037(0.013-0.092)\end{array}$ & 14 & SA \\
\hline
\end{tabular}

\begin{tabular}{|c|c|c|c|c|c|c|c|c|c|}
\hline \multirow{2}{*}{$\begin{array}{l}\text { ID } \\
\text { no. }\end{array}$} & \multirow[b]{2}{*}{ with three CaMeLeu substitutions } & \multirow{2}{*}{\multicolumn{2}{|c|}{ HPLCa $^{a}$}} & \multirow[b]{2}{*}{$C Z E^{b}$} & \multicolumn{2}{|c|}{ MS (mono)c } & \multirow{2}{*}{$\begin{array}{l}\text { rel. } \\
\text { potencies } \\
\text { in vitro }\end{array}$} & \multirow[b]{2}{*}{$\mathrm{IA}^{\mathrm{e}}$} & \multirow{2}{*}{$\begin{array}{l}\text { dur. of } \\
\text { action }\end{array}$} \\
\hline & & & & & calcd & found & & & \\
\hline 21 & 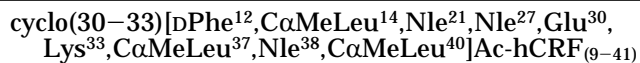 & & 96 & 97 & 3975.2 & 3975.3 & $0.50(0.23-1.0)$ & 6 & MA \\
\hline 22 & 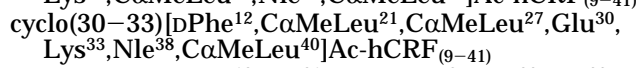 & & 98 & 96 & 3975.27 & 3975.34 & $0.43(0.19-0.93)$ & 13 & LA \\
\hline 23 & 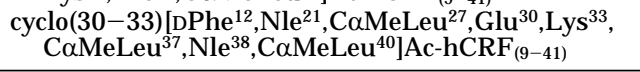 & & 90 & 90 & 3975.3 & 3975.2 & $0.75(0.37-1.5)$ & 19 & LA \\
\hline \multirow{2}{*}{$\begin{array}{l}\text { ID } \\
\text { no. }\end{array}$} & & & & & \multicolumn{2}{|c|}{ MS (mono) ${ }^{c}$} & \multirow{2}{*}{$\begin{array}{l}\text { rel. } \\
\text { potencies } \\
\text { in vitro }\end{array}$} & \multirow[b]{2}{*}{$\mathrm{IA}^{\mathrm{e}}$} & \multirow{2}{*}{$\begin{array}{l}\text { dur. of } \\
\text { action }\end{array}$} \\
\hline & with four C $\alpha$ MeLeu substitutions & HPLCa & & CZE ${ }^{b}$ & calcd & found & & & \\
\hline 24 & 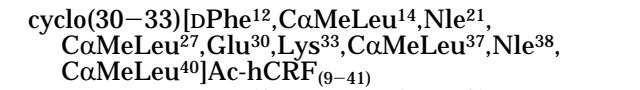 & 97 & & 96 & 3989.3 & 3989.4 & $0.60(0.33-1.1)$ & 7 & LA \\
\hline 25 & 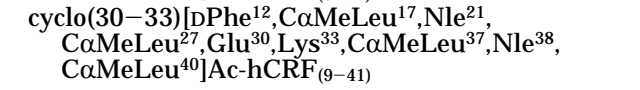 & 98 & & 95 & 3973.32 & 3973.3 & $0.22(0.08-0.55)$ & 0 & SA \\
\hline
\end{tabular}

a Percent purity determined by HPLC using the following buffer system: $\mathrm{A}=\mathrm{TEAP}(\mathrm{pH} 2.5)$ and $\mathrm{B}=60 \% \mathrm{CH}_{3} \mathrm{CN} / 40 \% \mathrm{~A}$ with a gradient slope of $1 \% \mathrm{~B} / \mathrm{min}$, at flow rate of $0.2 \mathrm{~mL} / \mathrm{min}$ on a Vydac $\mathrm{C}_{18}$ column $\left(0.25 \times 15 \mathrm{~cm}, 5 \mu \mathrm{m}\right.$ particle size, $300 \AA$ pore size). Detection at $214 \mathrm{~nm}$. ${ }^{b} \mathrm{Capillary} z o n e$ electrophoresis (CZE) was done using a Beckman P/ACE System 2050 controlled by an IBM Personal System/2 model $50 Z$ and using a ChromJ et integrator. Field strength of $15 \mathrm{kV}$ at $30^{\circ} \mathrm{C}$, mobile phase: $100 \mathrm{mM}$ sodium phosphate $\left(85: 15, \mathrm{H}_{2} \mathrm{O}: \mathrm{CH}_{3} \mathrm{CN}\right.$ ) pH 2.50 , on a Supelco P175 capillary (363 $\mu \mathrm{m} \mathrm{OD} \times 75 \mu \mathrm{m} \mathrm{ID} \times 50 \mathrm{~cm}$ length). Detection at $214 \mathrm{~nm}$. ${ }^{\mathrm{C}}$ The observed $\mathrm{m} / \mathrm{z}$ of the monoi sotope compared with the calculated [M $\left.+\mathrm{H}\right]^{+}$monoisotopic mass. ${ }^{d}$ Antagonist potencies are relative to that of cyclo(30-33)[DPhe $\left.{ }^{12}, \mathrm{Nle}^{21}, \mathrm{Glu}^{30}, \mathrm{DH}^{3 \mathrm{~S}^{32}}, \mathrm{Lys}^{33}, \mathrm{Nle}^{38}\right] \mathrm{hCRF}(12-41)$ in the in vitro rat pituitary cell culture assay, with $95 \%$ confidence limits in parentheses. e The percent intrinsic activity (IA) of each of the antagonists is calculated by determining the level of secretion caused by the highest dose of antagonist (in the absence of oCRF) minus basal secretion and dividing that number by the level of secretion of $1 \mathrm{nM}$ oCRF minus basal secretion and multiplying the result by $100 .{ }^{\mathrm{f}}$ Definition of duration of action in the adrenalectomized rat after iv administration of $25 \mu \mathrm{g}$ peptide/rat. Short acting: duration of action less than $90 \mathrm{~min}$. Medium acting: shows complete inhibition at 120 min and no detectable standard error, with partial recovery at $180 \mathrm{~min}$. Long acting: shows complete inhibition at 240 min and no detectable standard error, with partial recovery at $300 \mathrm{~min}$. 
to residues 10,12, 14, 15, 36, 37, and 38 in hCRF. Additionally, Leu is found at position 40 of tilapia CRF . We also introduced $\mathrm{C} \alpha \mathrm{MeL}$ eu at position 13 instead of histidine and at position 41 instead of Ile where Beyermann et al. had found it to be compatible. ${ }^{62}$

In vitro potencies relative to that of $\mathrm{Cyclo}(30-33)$ $\left[\mathrm{DPhe}^{12}, \mathrm{Nle}^{21}, \mathrm{Glu}^{30}, \mathrm{DH}^{3 s^{32}}, \mathrm{Lys}^{33}, \mathrm{Nle}^{38} \mathrm{hhCRF}_{(12-41)}(\mathbf{1}) \mathrm{re}\right.$ sulting from the introduction of $\mathrm{C} \alpha \mathrm{MeL}$ eu at positions 10 (4), 13 (5), 14 (6), 15 (7, 8), 17 (9), 18 (10, 11), 19 (12, 13), 21 (14), 24 (15), 36 (16), 37 (17), 38 (18), 40 (19), and 41 (20) of 2 are given in Table 1. Additionally three related analogues were synthesized that were shorter by two residues $(\mathbf{7}, \mathbf{1 0}, \mathbf{1 2})$ to test the hypothesis that improved biological properties brought about by the introduction of $\mathrm{C} \alpha \mathrm{MeL}$ eu would compensate for the loss of duration of action in the adx rat, observed when residues 9 and 10 were deleted. $^{1}$

While the relative in vitro potencies varied from 2 to 4\% (20) to $430 \%$ (14), introduction of C $\alpha$ M eLeu at those different positions similarly resulted in analogues with durations of action that varied from shorter to longer than that of the parent analogue $\mathbf{2}$. We arbitrarily decided that an analogue would be identified as having an intermediate duration of action when its subcutaneous injection to adx rats at a dose of $100 \mu \mathrm{g} / \mathrm{kg}$ in 200 $\mu \mathrm{L}$ buffer would maximally inhibit ACTH secretion in all rats (4-7 rats per point) for $2 \mathrm{~h}$ with partial recovery at $3 \mathrm{~h}$. Analogues that had a duration of action shorter than that of $\mathbf{2}$ were those with C $\alpha$ MeLeu at positions $15(\mathbf{7}, \mathbf{8}), 17(\mathbf{9}), 19(\mathbf{1 2}, \mathbf{1 3})$, and $41(\mathbf{2 0})$ (Figure $1 \mathrm{~A}-\mathrm{C})$. There does not seem to be any correlation between potencies in vitro and duration of action in vivo. Indeed, there is as much as a 50 -fold difference between the in vitro potency of the most ( $110 \%$ for 7 ) and least ( $2-4 \%$ for 20) potent analogues of this series of short acting analogues, which is not surprising in view of the expected complexity of the pharmacokinetics of these relatively large peptides.

While $\mathbf{2 0}$ may be the least potent member of this series in vitro and also short acting for steric reasons (native substitutions in the CRF family include Ala, Ile, $\mathrm{Val}$, and Phe, yet [DAla ${ }^{41}$ ]oCRF is 100 times less potent than oCRF ${ }^{63}$ ), it is not possible to rationalize why $\mathbf{7}, \mathbf{8}$, and 12, which are statistically equipotent to $\mathbf{2}$ in vitro, would be shorter acting in vivo. It should be noted, when examining Figure $1 \mathrm{~A}$, that the distinction between the qualitatives short, medium, and long acting (defined in the legend of Table 1) is arbitrary and is only used for the purpose of the discussion. In Figure 1A for example, the durations of action of analogues 20, 15, and $\mathbf{4}$ are certainly not different. In Figure 1C on the other hand, analogues are more clearly grouped in three distinct categories. Analogues that had duration of action similar to that of $\mathbf{2}$ are those with $\mathrm{C} \alpha \mathrm{MeLeu}$ at positions 10 (4), 13 (5), 14 (6), 18 (10), 21 (14), 24 (15), 36 (16), and 38 (18). Again, there does not seem to be much correlation between in vitro potencies spanning from $18 \%$ (4) to $430 \%(\mathbf{1 4})$ in this series of analogues exhibiting intermediate duration of action. We conclude from these data that the $\mathrm{C} \alpha \mathrm{MeL}$ eu substitution at these positions has no effect on any of the parameters suspected to influence duration of action (secondary structure that may influence affinity and/or resistance to enzymatic degradation). Clearly of more interest are those posi-
A

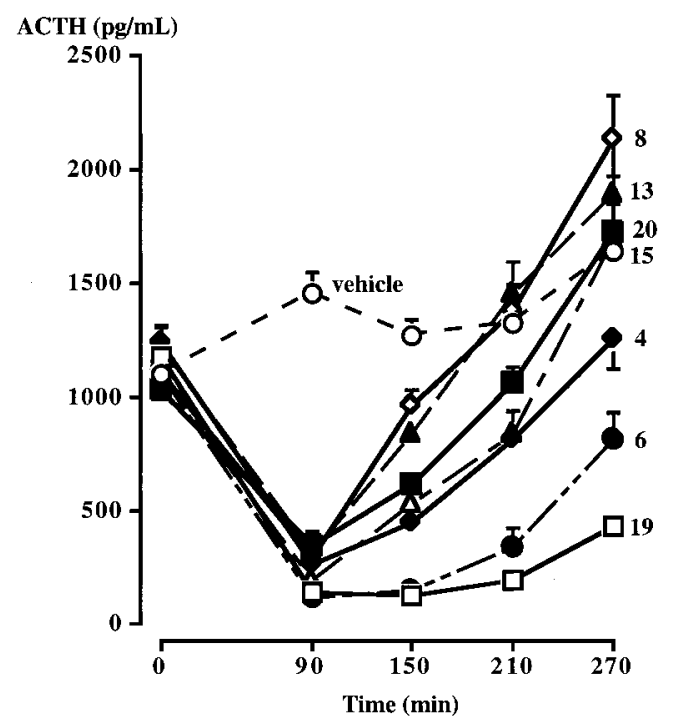

B

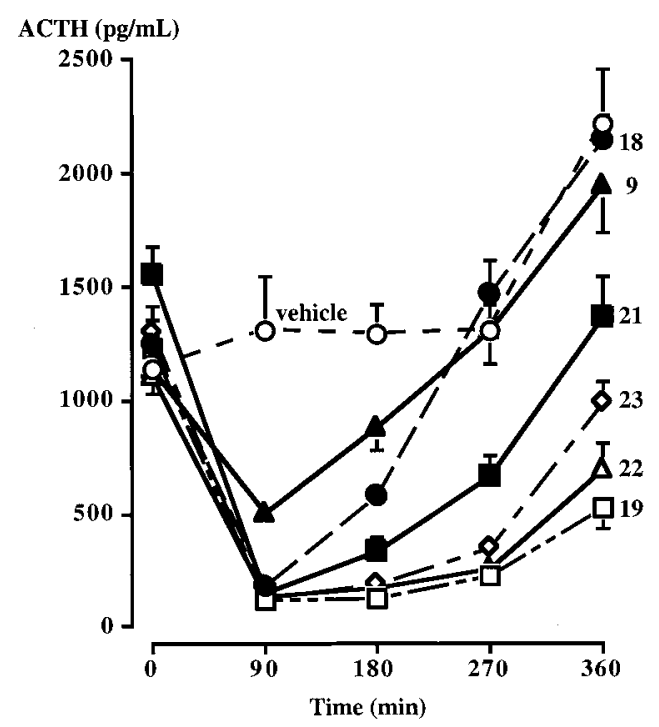

C

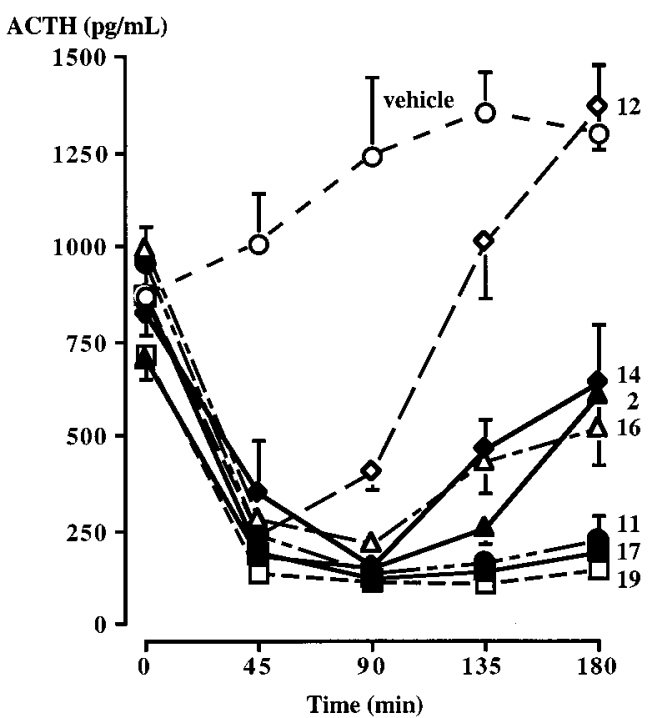

Figure 1. (A-C) Effect of CRF antagonists ( $25 \mu \mathrm{g} / \mathrm{rat}$ iv) on ACTH secretion in adx rats. Each point represents the mean \pm SEM of 4-7 animals. When not visible, SEM are encompassed within the symbols.

tions where CaMeLeu substitutions resulted in increased duration of action. These positions are 18 (11), 37 (17), and 40 (19). In this case, in vitro potencies are 
less scattered and only vary from $51 \%$ (17) to $110 \%$ (19). This emphasizes the importance of in vivo data in sel ecting those modifications more likely to improve the desirable properties (potency and duration of action) of CRF antagonists. Finally, it should be noted that while the first significant decrease in plasma ACTH levels was measured at 90 min in Figure $1 A, B$, earlier experiments as well as results shown in Figure $1 \mathrm{C}$ (first time point at $45 \mathrm{~min}$ ) show that the onset of action of CRF antagonists is al most immediate and profound.

Next, we investigated the effect of more than two C $\alpha$ MeLeu substitutions on in vitro potencies and duration of action of these CRF antagonists. As indicated by the in vivo data shown for astressin B (19) (Figure $1 A-C)$, this anal ogue has been consistently the longest acting, and its inhibition curve could be used as a reference point. As can be seen, the duration of action of and extent of inhibition of ACTH by 19 is consistent from assay to assay. We therefore asked whether additional $\mathrm{C} \alpha \mathrm{MeLeu}$ substitutions would further increase duration of action. In the few analogues synthesized and tested (21-23), this was not the case; introduction of C $\alpha$ MeLeu at position 14 (21) was detrimental or without additional improvement at positions 21 and 37 (22, 23). Finally, two CaMeLeu substitutions in addition to those at positions 27 and 40 had either no additional positive effect (24) or was deleterious (25). In vivo data for analogues 3, 5, 7, 10, 22, and $\mathbf{2 5}$ are not shown as they are similar to those shown in Figures 1A-C.

Reinvestigation of the role of residues at positions 9 and 10 with respect to duration of action confirmed earlier results that these residues were important for sustained duration of action. ${ }^{1}$ Antagonists 7, 12, and 10 (analogues that lack these residues) are either as short acting or shorter acting than their parent analogues (8, 13, and $\mathbf{1 1}$, respectively).

Figure 1B shows that the duration of action of 19 extends beyond $6 \mathrm{~h}$ at the dose of ca. $25 \mu \mathrm{g} / \mathrm{rat}$. We hypothesized that such duration of action could be modulated by the way the peptide was delivered and by the excipient in which it was delivered.

It is generally accepted that sc administration of peptides extends duration of action as compared to iv administration and that the excipient used may also influence rel ease of the peptide from the injection site. We investigated the effect, over $24 \mathrm{~h}$, of sc administration of graded doses of $\mathbf{1 9}$ in an aqueous buffer (Figure $2 \mathrm{~B}$ ) and peanut oil (Figure 2C) compared to iv administration of an equivalent dose (F igure 2A). Intravenous administration of 19 at a dose of $100 \mu \mathrm{g} / \mathrm{rat}$ inhibited ACTH secretion at 6 but not $12 \mathrm{~h}$, suggesting possible degradation and elimination. A similar profile of inhibition was obtained with $30 \mu \mathrm{g} / \mathrm{rat}(1 / 3$ the dose administered iv) when administered sc while 100 and $300 \mu \mathrm{g} /$ rat significantly inhibited ACTH secretion for more than $24 \mathrm{~h}$ (Figure 2B). The effect of 19 on ACTH secretion in adx rats was even more dramatic after sc administration in peanut oil, and inhibition was observed for more than $24 \mathrm{~h}$ after administration of only $30 \mu \mathrm{g}$ of $\mathbf{1 9}$ per rat (Figure 2C). For the sake of simplicity, as we expect 19 to be widely used for biological studies, and because of its homology with astressin, we decided to call it astressin B.
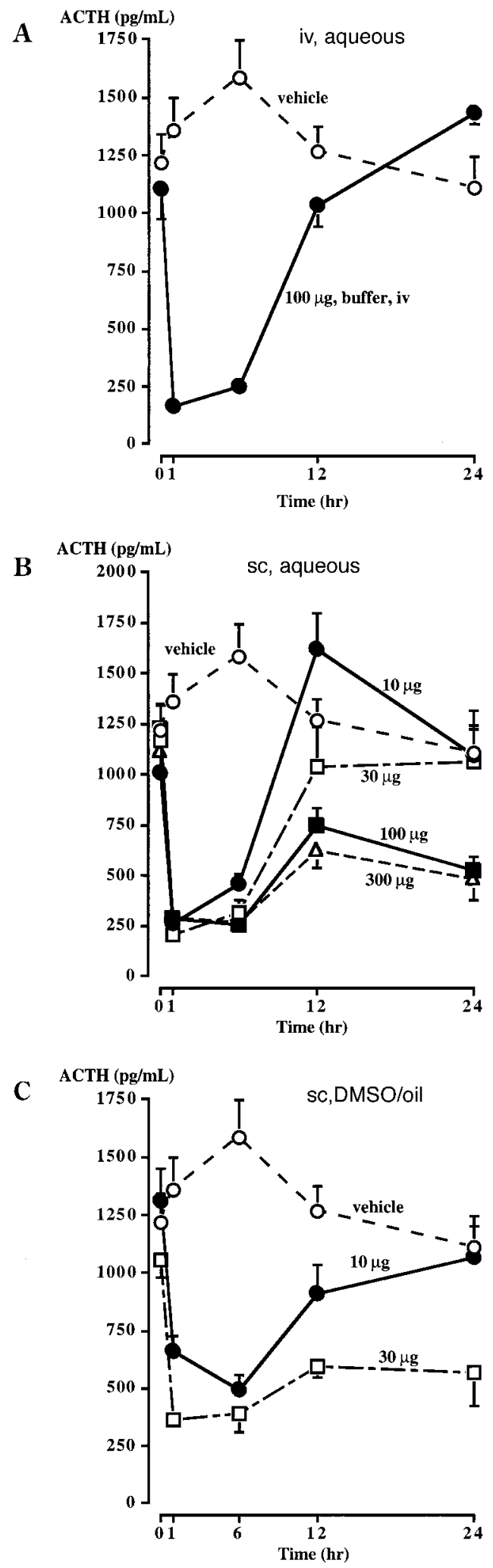

Figure 2. (A) Effect of astressin B (19, $100 \mu \mathrm{g} / \mathrm{adx}$ rat iv) on ACTH secretion. Each point represents the mean \pm SE M of 6 animals. When not visible, SEM are encompassed within the symbol. (B) Effect of astressin B (19, graded doses/adx rat, sc in aqueous buffer) on ACTH secretion. Each point represents the mean \pm SEM of 5-8 animals. When not visible, SEM are encompassed within the symbol. (C) E ffect of astressin B (19, graded doses/adx rat, SC in DMSO/peanut oil) on ACTH secretion. Each point represents the mean \pm SEM of 6 or 7 animals. When not visible, SEM are encompassed within the symbol. 


\section{Experimental Section}

Synthesis of CRF Analogues. All analogues shown in Table 1 were synthesized either manually or on a Beckman 990 peptide synthesizer using the solid-phase approach, the MBHA resin, ${ }^{2}$ and the Boc strategy with orthogonal protection ( $\mathrm{F} \mathrm{moc}$ and $\mathrm{OF} \mathrm{m}$ ) of the side chains of residues to be cyclized. ${ }^{51}$ Amino acid derivatives Boc-Ala, Boc-Arg(Tos), Boc-Asn(Xan), Boc-Asp(cHex), Boc-GIn(Xan), Boc-Glu(cHex), Boc-His(Tos), Boc-lle, Boc-Met, Boc-Leu, Boc-Phe, Boc-Pro, Boc-Ser(Bzl), Boc$\operatorname{Thr}(\mathrm{B} z \mathrm{l}), \mathrm{Boc}-\mathrm{Tyr}(2-\mathrm{Br}-\mathrm{Cbz})$, and $\mathrm{B} \circ \mathrm{c}-\mathrm{Val}$ were obtained from Bachem I nc. (Torrance, CA), Chem-Impex International (Wood Dale, IL), and Cal biochem (San Diego, CA). Boc-C $\alpha M$ e-L-Leu, 64 Boc-Glu(OFm), and Boc-Lys(F moc) ${ }^{65}$ were synthesized as described earlier. All solvents were reagent grade or better. TFA, $50-60 \%$ in DCM ( $1 \% \mathrm{~m}$-cresol), was used to remove the Boc group. Main chain assembly was mediated by DIC. Threefold excess protected amino acid was used based on the original substitution of the MBHA resin. When carrying out the synthesis on a synthesizer, coupling time was $90-120 \mathrm{~min}$ followed by recoupling after residue 32 (with the exception of glycine and alanine residues which were not recoupled). Automatic acetylation (excess acetic anhydride in DCM for 15 min) was carried out after addition of each amino acid. When synthesized manually, recouplings were carried out only when necessary and acetylations only when recoupling could not yield negative ninhydrin tests. ${ }^{56}$ Deprotection of the Fmoc group was achieved using a fresh solution of $20 \%$ piperidine/ DMF or NMP $(2 \times 10 \mathrm{~min})$ followed by sequential washes with DMF, MeOH, 10\% TEA/DCM, and DCM. Lactam formation was mediated using TBTU or HBTU in DMF or NMP. Best results were obtained when the peptide chain was assembled in its entirety prior to deavage of the $\mathrm{Fmoc}$ and Ofm protecting groups and cyclization as shown earlier. ${ }^{52}$ The peptides were cleaved and deprotected in HF in the presence of anisole (5$10 \%, v / v)$ and purified using RP-HPLC and three solvent systems (TEAP at pH 2.25, TEAP at pH 4.5-6.5, and $0.1 \%$ TFA, successively). ${ }^{57,58}$

Scaled-Up Synthesis and Purification of Cyclo (30-33) [DPhe ${ }^{12}, \mathrm{C} \alpha \mathrm{MeLeu}^{27}, \mathrm{Glu}^{30}, \mathrm{~L} \mathrm{ys}^{33}, \mathrm{Nle}^{21,38}, \mathrm{C} \alpha \mathrm{Me}$ Leu $^{40}$ ]h/rCRF 9-41 (Astressin B, 19). For most analogues prepared in this investigation, $1.0-2.0 \mathrm{~g}(0.5 \mathrm{mmol} / \mathrm{g})$ of MBHA resin were deprotected and neutralized according to the protocol described earlier in this section. Here, however, we detail the scale-up of one of the most potent analogues starting with $7.1 \mathrm{~g}$ of $0.5 \mathrm{mmol} / \mathrm{g}$ substituted MBHA resin, (3.55 mmol). The Boc-CoMeLeu-OH, Boc-Glu(OFm)-OH, and Boc-Lys(Fmoc)-OH were prepared in-house whereas all other amino acids were commercially available. All coupling reactions were monitored by ninhydrin test ${ }^{56}$ and were facilitated by using $0.1 \mathrm{M}$ DIC for $1-3 \mathrm{~h}$ with the exception of $\mathrm{His}(\mathrm{Tos}){ }^{32}$ $\mathrm{C} \alpha \mathrm{MeLeu},{ }^{27}$ and $\mathrm{C} \alpha \mathrm{MeL}$ eu ${ }^{40}$ which required the use of 3 equiv of BOP/DIPEA to drive the reaction to completion. Because deprotected $\mathrm{C} \alpha \mathrm{M}$ eLeu does not give a positive ninhydrin test result, the residue following CaMeLeu was always coupled twice and followed by acetylation. In addition, $\mathrm{Asn}^{34}$ required a double coupling step. After incorporation of the last amino acid, the $\mathrm{N} \alpha-\mathrm{B} \propto \mathrm{c}$ protecting group was removed and the $\mathrm{N}$-terminus was acetylated. The OF m/F moc groups of $\mathrm{Glu}^{30}$ and $\mathrm{Lys}^{33}$, respectively, were removed by two 10 min treatments with $20 \%$ piperidine in NMP. The formation of the bridge was accomplished in $12 \mathrm{~h}$ (negative ninhydrin test) using BOP/DIEA at room temperature. A total of $15.4 \mathrm{~g}$ of protected peptide resin was obtained and was cleaved in three batches $(5.3,5.0$, and $4.9 \mathrm{~g})$ by anhydrous HF $(50 \mathrm{~mL})$ in the presence of anisole $(5 \mathrm{~mL})$ at $0^{\circ} \mathrm{C}$ for $90 \mathrm{~min}$. The crude peptide was precipitated and washed with anhydrous diethyl ether, filtered, extracted from the resin with $150 \mathrm{~mL}$ of $0.1 \%$ TFA in $\mathrm{CH}_{3} \mathrm{CN} / \mathrm{H}_{2} \mathrm{O}(60: 40)$, and lyophilized to give 2.71, 2.13, and 2.10 $\mathrm{g}$ of crude product, respectively. Each batch of crude peptide material was independently analyzed by HPLC and determined to be of similar composition so the three batches were combined prior to purification. Preparative purification was performed in three stages as described above. First the peptide $(1.5-2.0 \mathrm{~g})$ was dissolved in $300 \mathrm{~mL}$ of buffer A (TEAP pH
2.25) and eluted with buffer $B\left(75 \% \mathrm{CH}_{3} \mathrm{CN}\right.$ in $\left.\mathrm{A}\right)$, with a gradient from 35 to $55 \%$ B in 60 min (retention time was ca. $30 \mathrm{~min}$ ). Approximately 20 fractions containing $50-100 \mathrm{~mL}$ were screened under isocratic conditions $(76 \% \mathrm{~B}$, retention time was ca. $4 \mathrm{~min}$ ); enriched fractions containing the desired product with purity $>85 \%$ from each of the four separate runs were identified and pooled. Fractions of lower purity (65-85\%) were pooled separately and reloaded for an additional TEAP $\mathrm{pH} 2.25$ run from which additional fractions with $>85 \%$ purity were isolated. In the second system, the pooled fractions (>85\% pure) were diluted $1: 1$ with $\mathrm{H}_{2} \mathrm{O}$ and the $\mathrm{pH}$ was adjusted to 4 with TEA. This solution was loaded onto the same $C_{18}$ cartridge in two runs. The peptide was eluted using buffer A:TEAP pH 4.3 and buffer $\mathrm{B}: 75 \% \mathrm{CH}_{3} \mathrm{CN}$ in TEAP $\mathrm{pH} 4.3$, with a gradient from 40 to $60 \%$ B in $60 \mathrm{~min}$. A total of $15-20$ fractions containing $30-50 \mathrm{~mL}$ each were screened; 4 fractions with purities $>90 \%$ were pooled from each run. In the final step, the pooled fractions (>90\% pure in ca. $400 \mathrm{~mL}$ ) were diluted with $\mathrm{H}_{2} \mathrm{O}(400 \mathrm{~mL})$ containing $1 \mathrm{~mL}$ of TFA. This solution was loaded and eluted by using buffer A:0.1\% TFA/ $\mathrm{H}_{2} \mathrm{O}$ and $\mathrm{B}: 0.1 \%$ TFA in $\mathrm{CH}_{3} \mathrm{CN} / \mathrm{H}_{2} \mathrm{O}$ (75:25), with a gradient from 30 to $80 \%$ B in 40 min (retention time was ca. 30 min). A total of 11 fractions containing $30-50 \mathrm{~mL}$ each were screened; 3 fractions ( $150 \mathrm{~mL}$ ) were pool ed that showed purity $>95 \%$. Side fractions containing less than $10 \%$ hydrophilic and hydrophobic impurities relative to the desired product were reloaded, and an additional amount of highly purified 19 was added to the pool prior to lyophilization. Yield of highly purified 19 was $564 \mathrm{mg}(126 \mu \mathrm{mol}), 3.5 \%$ of theoretical amount from the original substitution of the MBHA resin.

Characterization of CRF Analogues. Peptides were characterized as shown in Table 1 and below. Most analogues were greater than $95 \%$ pure with no impurity greater than $1 \%$ using independent HPLC and CZE criteria and had expected masses.

RP-HPLC. In addition to determining the purity of the peptides in an acidic system (see Table 1 legend), most of the analogues were also analyzed using $0.05 \%$ TEAP at pH 6.8 and a Vydac $C_{8}$ column $(0.21 \times 15 \mathrm{~cm})$ at a flow rate of 0.2 $\mathrm{mL} / \mathrm{min}$ with slightly varying gradient slopes. Percent purity was in the range of that found with CZE or with HPLC under acidic conditions.

Capillary Zone E lectrophoresis. Capillary zone electrophoresis (CZE) was carried out using a Beckman P/ACE System 2000 controlled by an IBM Personal System/2 model $50 Z$ and using a Chromj et integrator. Electrophoresis was performed in $0.1 \mathrm{M}$ sodium phosphate ( $\mathrm{pH} 2.5)$, except for $\alpha$-hel-CRF ${ }_{(9-41)}$ which was measured in $0.1 \mathrm{M}$ sodium borate (pH 8.5). Acetonitrile (15\%) was added to the buffers in order to gain sharp elution profiles.66

Mass Spectroscopy. LSI MS mass spectra were measured with a J EOL J MS-HX110 double focusing mass spectrometer (J EOL, Tokyo, J apan) fitted with a $\mathrm{Cs}^{+}$gun. An accel erating voltage of $10 \mathrm{kV}$ and $\mathrm{Cs}^{+}$gun voltage of $25 \mathrm{kV}$ were employed; for further details, see ref 52. Calculated values for protonated molecule ions were in agreement with those observed using LSIMS.

In Vitro Pituitary Cell Culture Assay. Rat anterior pituitary glands from male Sprague-Dawley rats were dissociated by col lagenase treatment and plated $\left(0.16 \times 10^{6}\right.$ cells/ well in 48-well plates) in medium containing $2 \%$ fetal bovine serum. ${ }^{61}$ Three days after plating, the cells were washed three times with fresh medium containing $0.1 \%$ bovine serum albumin (BSA) and incubated for $1 \mathrm{~h}$. Following the $1 \mathrm{~h}$ preincubation, the cells were washed once more and the test peptides at five concentrations were applied in the presence of $1 \mathrm{~nm} \mathrm{hCRF}$. At the end of a $3 \mathrm{~h}$ incubation period, the media were collected and the level of ACTH was determined by radioimmunoassay (Diagnostic Products Corporation).

In Vivo adx Rat Assay. Adult male rats were adrenalectomized under halothane anesthesia 8 days prior to the experiments. Their diet was supplemented with oranges, and their water contained $0.9 \% \mathrm{NaCl}$. Adrenalectomized rats maintained in a temperature-controlled environment, with 
ready access to food and no lurking predators against which to fight (i.e., kept in a nonstressful environment), are quite healthy. They gain weight, have a shiny fur, and are very active. Their life expectancy is normal. They mate and carry and nurse their young with no problems. Such rats were equipped with indwelling jugular cannulae ${ }^{67} 48 \mathrm{~h}$ prior to the iv injection of the vehicle or the antagonists. All protocols were approved by the Salk Institute IACUC. Analogues were first diluted in sterile distilled water, and the $\mathrm{pH}$ was adjusted to 7.0. Further dilutions were made in $0.04 \mathrm{M}$ phosphate buffer, $\mathrm{pH} 7.4$, containing $0.1 \%$ BSA and $0.01 \%$ ascorbic acid. The same buffer and dilutions were used for the sc administration (Figure 2B). All peptides remained in solution under these conditions. For the experiment shown in Figure $2 \mathrm{C}$, peptide was dissolved in DMSO $(10 \mathrm{mg} / \mathrm{mL})$ and diluted to the desired concentration with peanut oil (Sigma). Blood samples were obtained immediately before treatment as well as at regular intervals. Decanted plasma were frozen until assayed for ACTH concentrations with a commercially available kit (AIlegro kit, Nichols Institute, San J uan Capistrano, CA). ${ }^{67}$

Acknowledgment. This work was supported in part by NIH Grant DK-26741 (J .R.), The Hearst F oundation, and the Foundation for Research, California Division. Drs. W. Vale and C. Rivier are FR investigators. We thank Dr. A. Grey Craig for mass spectrometric analyses; R. Kaiser, T. Goedken, C. Donaldson, and Y. Haas for technical assistance; L. Cervini for critical review of the manuscript; and D. Doan for manuscript preparation.

\section{References}

(1) Rivier, J .; Gulyas, J .; Corrigan, A.; Craig, A. G.; Martinez, V.; Taché, Y.; Vale, W.; Rivier, C. Astressin analogues (CRF antagonists) with extended duration of action in the rat. J. Med. Chem. 1998, 41, 5012-5019.

(2) Hernandez, J .-F.; Kornreich, W.; Rivier, C.; Miranda, A.; Yamamoto, G.; Andrews, J.; Taché, Y.; Vale, W. W.; Rivier, J. E. Synthesis and relative potencies of new constrained CRF antagonists. J. Med. Chem. 1993, 36, 2860-2867.

(3) Guillemin, R.; Rosenberg, B. Humoral hypothalamic control of anterior pituitary: a study with combined tissue cultures. Endocrinology 1955, 57, 599-607.

(4) Saffran, M.; Schally, A. V. The release of corticotrophin by anterior pituitary tissue in vitro. Can. J . Biochem. Physiol. 1955, 33, 408-415.

(5) Vale, W.; Spiess, J .; Rivier, C.; Rivier, J . Characterization of a 41 residue ovine hypothalamic peptide that stimulates the secretion of corticotropin and $\beta$-endorphin. Science 1981, 213, 1394-1397.

(6) Rivier, J .; Spiess, J .; Vale, W. Characterization of rat hypothalamic corticotropin-releasing factor. Proc. Natl. Acad. Sci. U.S.A. 1983, 80, 4851-4855.

(7) Shibahara, S.; Morimoto, Y.; Furutani, Y.; Notake, M.; Takahashi, H.; Shimizu, S.; Horikawa, S.; Numa, S. I solation and sequence analysis of the human corticotropin-releasing factor precursor gene. Embo. J . 1983, 2 (5), 775-779.

(8) Rivier, C.; Plotsky, P. M. Mediation by corticotropin-releasing factor (CRF) of adenohypophysial hormone secretion. In Annual Review of Physiology; Berne, R. M., Ed.; Academic Press: Palo Alto, CA, 1986; Vol. 48, pp 475-494.

(9) Irwin, M. R.; Vale, W.; Britton, K. T. Central corticotropinreleasing factor suppresses natural killer cytotoxicity. Brain Behav. Immun. 1987, 1, 81-87.

(10) Rivest, S.; Rivier, C. The role of corticotropin-releasing factor and interleukin-1 in the regulation of neurons controlling reproductive functions. Endocr. Rev. 1995, 16, 177-199.

(11) Brown, M.; Fisher, L. Regulation of the autonomic nervous system by corticotropin-releasing factor. In Corticotropin-rel easing factor: Basic and clinical studies of a neuropeptide; DeSouza, E., Nemeroff, C. B., Eds.; CRC Press: Boca Raton, FL, 1990; pp 292-298.

(12) Fisher, L. A. Central actions of corticotropin-rel easing factor on autonomic nervous activity and cardiovascular functioning. In Proceedings of the Ciba Foundation Symposium No. 172 on Corticotropin-Releasing Factor; Chadwick, D. J ., Marsh, J ., Ackrill, K., Eds.; J ohn Wiley \& Sons: New York, 1993; pp 243257.
(13) Brown, M. R. Brain peptide regulation of autonomic nervous and neuroendocrine functions. In Stress Neurobiology and Neuroendocrinology; Brown, M. R., Koob, G. F., Rivier, C., Eds.; Marcel Dekker: New York, 1991; pp 193-215.

(14) Heinrichs, S. C.; Menzaghi, F.; Schulteis, G.; Koob, G. F.; Stinus, L. Suppression of corticotropin-releasing factor in the amygdala attenuates aversive consequences of morphine withdrawal. Behav. Pharmacol. 1995, 6, 74-80.

(15) Menzaghi, F.; Rassnick, S.; Heinrichs, S.; Baldwin, H.; Pich, E.; Weiss, F.; Koob, G. The role of corticotropin-releasing factor in the anxiogenic effects of ethanol withdrawal. Ann. NY Acad. Sci. 1994, 739, 176-184.

(16) Koob, G. F.; Heinrichs, S. C.; Pich, E. M.; Menzaghi, F.; Baldwin, H.; Miczek, K.; Britton, K. T. The role of corticotropin-releasing factor in behavioural responses to stress. In Proceedings of the Ciba Foundtaion Symposium No. 172 on Corticotroin-Releasing Factor; Chadwick, D. J ., Marsh, J ., Ackrill, K., Eds.; J ohn Wiley \& Sons: New York, 1993; pp 277-295.

(17) Gold, P. W.; Wong, M.-L.; Chrousos, G. P.; Licinio, J . Stress system abnormalities in melancholic and atypical depression: molecular, pathophysiological, and therapeutic implications. Mol. Psychiat. 1996, 1, 257-264.

(18) Britton, K. T.; Lee, G.; Vale, W.; Rivier, J.; Koob, G. F. Corticotropin releasing factor (CRF) receptor antagonist blocks activating and 'anxiogenic' actions of CRF in the rat. Brain Res. 1986, 369, 303-306.

(19) Koob, G. F. Behavioral responses to stress-focus on corticotropin releasing factor. In Neurobiology and Neuroendocrinology of Stress; Brown, M. R., Rivier, C., Koob, G., Eds.; Marcel Dekker: New York, 1990; pp 255-274.

(20) Munck, A.; Guyre, P. M. Glucocorticoid physiology, pharmacology and stress. Adv. Exp. Med. Biol. 1986, 196, 81-96.

(21) Dallman, M. F.; Strack, A. M.; Akana, S. F.; Bradbury, M. J .; Hanson, E. S.; Scribner, K. A.; Smith, M. Feast and famine: critical role of glucocorticoids with insulin in daily energy flow. Front. Neuroendocrinol. 1993, 14, 303-347.

(22) Chen, R.; Lewis, K. A.; Perrin, M. H.; Vale, W. W. Expression cloning of a human corticotropin rel easing factor (CRF) receptor. Proc. Natl. Acad. Sci. U.S.A. 1993, 90, 8967-8971.

(23) Chang, C. P.; Pearse, R. V., II; O'Connell, S.; Rosenfeld, M. G. Identification of a seven transmembrane helix receptor for corticotropin-releasing factor and sauvagine in mammalian brain. Neuron 1993, 11, 1187-1195.

(24) Perrin, M.; Donaldson, C.; Chen, R.; Blount, A.; Berggren, T.; Bilezikjian, L.; Sawchenko, P.; Vale, W. I dentification of a second CRF receptor gene and characterization of a CDNA expressed in heart. Proc. Natl. Acad. Sci. U.S.A. 1995, 92, 2969-2973.

(25) Kishimoto, T.; Pearse, R. V., II; Lin, C. R.; Rosenfeld, M. G. A sauvagine/corticotropin-releasing factor receptor expressed in heart and skeletal muscle. Proc. Natl. Acad. Sci. U.S.A. 1995, 92, 1108-1112.

(26) Vita, N : Laurent, P. : efort S : Chalon, P : Lelias, J . M. Kaghad, M.; Le, F. G.; Caput, D.; Ferrara, P. Primary structure and functional expression of mouse pituitary and human brain corticotropin releasing factor receptors. FEBS Lett. 1993, 335, $1-5$.

(27) Lovenberg, T. W.; Liaw, C. W.; Grigoriadis, D. E.; Clevenger, W.; Chalmers, D. T.; DeSouza, E. B.; Oltersdorf, T. Cloning and characterization of a functionally distinct corticotropin-releasing factor receptor subtype from rat brain. Proc. Natl. Acad. Sci. U.S.A. 1995, 92, 836-840

(28) Perrin, M. H.; Donaldson, C. J .; Chen, R.; Lewis, K. A.; Vale, W. W. Cloning and functional expression of a rat brain corticotropin releasing factor (CRF) receptor. Endocrinology 1993, 133, 3058-3061.

(29) Martínez, V.; Rivier, J .; Wang, L.; Taché, Y. Central injection of a new corticotropin-releasing factor (CRF) antagonist, astressin blocks CRF - and stress-related alterations of gastric and colonic motor function. J. Pharmacol. Exp. Ther. 1997, 280, 754-760.

(30) Chen, C.; Dagnino, R., J r.; De Souza, E. B.; Grigoriadis, D. E.; Huang, C. Q.; Kim, K.; Liu, Z.; Moran, T.; Webb, T. R.; Whitten, J .P.; Xie, Y. F.; McCarthy, J . R. Design and synthesis of a series of non-peptide high-affinity human corticotropin-releasing factor 1 receptor antagonists. J. Med. Chem. 1996, 39, 4358-4360.

(31) Wustrow, D. J .; Capiris, T.; Rubin, R.; Knobelsdorf, J. A.; Akunne, H.; Davis, M. D.; Mackenzie, R.; Pugsley, T. A.; Zoski, K. T.; Heffner, T. G.; Wise, L. D. Pyrazolo[1,5-a]pyrimidine CRF-1 receptor antagonists. Bioorg. Med. Chem. Lett. 1998, 8 , 2067-2070.

(32) Hodge, C. N.; Aldrich, P. E. Wasserman, Z R.; Fernandez, C. H.; N emeth, G. A.; Arvanitis, A.; Cheeseman, R. S.; Chorvat, R. J .; Ciganek, E.; Christos, T. E.; Gilligan, P. J .; Krenitsky, P.; Scholfield, E.: Strucely, P. Corticotropin-releasing hormone receptor antagonists: Framework design and synthesis guided by ligand conformational studies. J . Med. Chem. 1999, 42, 819832. 
(33) Arvanitis, A. G.; Gilligan, P. J .; Chorvat, R. J .; Cheeseman, R. S.; Christos, T. E.; Bakthavatchalam, R.; Beck, J . P.; Cocuzza, A.J .; Hobbs, F. W.; Wilde, R. G.; Arnold, C.; Chidester, D.; Curry, M.; He, L.; Hollis, A.; Klaczkiewic, J .; Krenitsky, P.J .; Rescinito, J . P.; Scholfield, E.; Culp, S.; De Souza, E. B.; Fitzgerald, L.; Grigoriadis, D.; Tam, S. W.; Wong, Y. N.: Huang, S.-M.; Shen, H. L. Non-peptide corticotropin-releasing hormone antagonists: Syntheses and structure-activity relationships of 2-anilinopyrimidines and -triazines. J. Med. Chem. 1999, 42, 805-818.

(34) Chorvat, R. J .; Bakthavatchalam, R.; Beck, J. P.; Gilligan, P. J .; Wilde, R. G.; Cocuzza, A. J .; Hobbs, F. W.; Cheeseman, R. S.; Curry, M.; Rescinito, J . P.; Krenitsky, P.; Chidester, D.; Yarem J. A.; Klaczkiewicz, ]. D.; Hodge, C. N.; Aldrich, P. E.; Wasserman, Z. R.; Fernandez, C. H.; Zaczek, R.; Fitzgerald, L. W.; Huang, S.-M.; Shen, H. L.; Wong, Y. N.; Chien, B. M.; Quon, C. Y.; Arvanitis, A. Synthesis, corticotropin-rel easing factor receptor binding affinity, and pharmacokinetic properties of triazoloimidazo-, and pyrrolopyrimidines and -pyridines. J . Med. Chem. 1999, 42, 833-848.

(35) Whitten, J.P.; Xie, Y. F.; Erickson, P. E.; Webb, T. R.; De Souza, E. B.; Grigoriadis, D. E.; McCarthy, J. R. Rapid microscale synthesis, a new method for lead optimization using robotics and solution phase chemistry: Application to the synthesis and optimization of corticotropin-releasing factor ${ }_{1}$ receptor antagonists. J . Med. Chem. 1996, 39, 4354-4357.

(36) Chen, Y. L.; Mansbach, R. S.; Winter, S. M.; Brooks, E.; Collins, J .; Corman, M. L.; Dunaiskis, A. R.; Faraci, W. S.; Gallaschun, R. .; Schmidt, A.; Schulz, D. W. Synthesis and oral efficacy of a 4-(Butylethylamino)pyrrolo[2,3-d]pyrimidine: A centrally active corticotropin-rel easing factor ${ }_{1}$ receptor antagonist. J . Med. Chem. 1997, 40, 1749-1754.

(37) Schulz, D. W.; Mansbach, R. S.; Sprouse, J .; Braselton, J . P.; Collins, J .; Corman, M.; Dunaiskis, A.; Faraci, S.; Schmidt, A W.; Seeger, T.; Seymour, P.; Tingley, F. D., III; Winston, E. N.; Chen, Y. L.; Heym, J. CP-154,526: A potent and selective nonpeptide antagonist of corticotropin releasing factor receptors. Proc. Natl. Acad. Sci. U.S.A. 1996, 93, 10477-10482.

(38) Barquist, E.; Zinner, M.; Rivier, J .; Taché, Y. Abdominal surgeryinduced delayed gastric emptying in rats: role of CRF and sensory neurons. Am. J. Physiol. 1992, 262, G616-G620.

(39) Raybould, H. E.; Koel bel, C. B.; Mayer, E. A.; Taché, Y. Inhibition of gastric motor function by circulating corticotropin-releasing factor in anesthetized rats. J . Gastrointest. Motil. 1990, 2, 265272.

(40) Williams, C. L.; Peterson, J. M.; Villar, R. G.; Burks, T. F. Corticotropin-releasing factor directly mediates col onic responses to stress. Am. J. Physiol. 1987, 253, G582-G586.

(41) Taché, Y.; Maeda-Hagiwar, M.; Turkelson, C. M. Central nervous system action of corticotorpin-releasing factor to inhibit gastric empyting in rats. Am. J. Physiol. 1987, 253, G241-G245.

(42) Sheldon, R. J .; Qui, J . A.; Porreca, F.; Fisher, L. A. Gastrointestinal motor effects of corticotropin-releasing factor in mice. Regul. Pept. 1990, 28, 137-151.

(43) Pappas, T.; Debas, H.; Taché, Y. Corticotropin-releasing factor inhibits gastric emptying in dogs. Regul. Pept. 1985, 11, 193199.

(44) Lenz, H. J.; Burlage, M.; Raekdler, A.; Greten, H. Central nervous system effects of corticotropin-releasing factor on gastrointestinal transit in the rat. Gastroenterology 1988, 94, 598602.

(45) Broccardo, M.; Improta, G. Pituitary-adrenal and vagus modulation of sauvagine and CRF-induced inhibition of gastric emptying in rats. Eur. J . Pharmacol. 1990, 182, 357-362.

(46) Nozu, T.; Martínez, V.; Rivier, J .; Taché, Y. Peripheral urocortin delays gastric emptying: role of CRF 2 receptors. Am. J. Physiol.: Gastrointest. Liver Physiol. 1999, 39, G867-G874.

(47) Martínez, V.: Rivier, J.: Taché, Y. The new corticotropinreleasing factor (CRF) antagonist, Astressin is a potent inhibitor of peripheral CRF and abdominal surgery-induced delayed emptying in rats. J . Pharmacol. Exp. Ther. 1999, in press.

(48) Baram, T. Z.; Mitchell, W. G.; Haden, E. Inhibition of pituitaryadrenal secretion by a corticotropin releasing hormone antagonist in humans. Mol. Psychiat. 1996, 1, 320-324.

(49) Chrousos, G. P.; Gold, P. W. Editorial: A healthy body in a healthy mind - and vice versa - the damaging power of "uncontrollable" stress. J . Clin. Endocrinol. Metab. 1998, 83, 1842-1845.
(50) Dudley, D. J . I mmunoendocrinology of preterm labor: The link between corticotropin-releasing hormone and inflammation. Am. J . Obstet. Gynecol. 1999, 180, S251-S256.

(51) Felix, A. M.; Heimer, E. P.; Wang, C.T.; Lambros, T. J .; Fournier A.; Mowles, T. F.: Maines, S.; Campbell, R. M.; Wegrzynski, B B.; Toome, V.; Fry, D.; Madison, V. S. Synthesis, biological activity and conformational analysis of cyclic GRF analogues. Int. J. Pept. Prot. Res. 1988, 32, 441-454.

(52) Miranda, A.; Koerber, S. C.; Gulyas, J .; Lahrichi, S.; Craig, A. G.; Corrigan, A.; Hagler, A.; Rivier, C.; Vale, W.; Rivier, J. Conformationally restricted competitive antagonists of human/ rat corticotropin-releasing factor. J . Med. Chem. 1994, 37, 14501459.

(53) Miranda, A.; Lahrichi, S. L.; Gulyas, J .; Koerber, S. C.; Craig A. G.; Corrigan, A.; Rivier, C.; Vale, W. W.; Rivier, J. E. Constrained corticotropin releasing factor (CRF) antagonists with $\mathrm{i}-(\mathrm{i}+3)$ Glu---Lys bridges. J . Med. Chem. 1997, 40, 36513658.

(54) Rivier, J .; Lahrichi, S. L.; Gulyas, J .; Erchegyi, J .; Koerber, S C.; Craig, A. G.; Corrigan, A.; Rivier, C.; Vale, W. Minimal-size constrained corticotropin releasing factor agonists with $\mathrm{i}-(\mathrm{i}+3)$ Glu-Lys and Lys-Glu bridges. J. Med. Chem. 1998, 41, 26142620

(55) Hudson, D. J . Methodological implications of simultaneous solidphase peptide synthesis. 1. Comparison of different coupling procedures. J . Org. Chem. 1988, 53, 617-624.

(56) Kaiser, E.; Colescott, R. L.; Bossinger, C. D.; Cook, P. I. Color test for detection of freeterminal amino groups in the solid-phase synthesis of peptides. Anal. Biochem. 1970, 34, 595-598.

(57) Hoeger, C.; Galyean, R.; Boublik, J .; McClintock, R.; Rivier, J. Preparative reversed phase high performance liquid chromatography. II. Effects of buffer $\mathrm{pH}$ on the purification of synthetic peptides. Biochromatography 1987, 2, 134-142.

(58) Rivier, J. Use of trialkylammonium phosphate (TAAP) buffers in reverse phase HPLC for high resolution and high recovery of peptides and proteins. J . Liq. Chromatogr. 1978, 1, 343-367.

(59) Koerber, S. C.; Gulyas, J .; Lahrichi, S. L.; Corrigan, A.; Craig A. G.; Rivier, C.; Vale, W. W.: Rivier, J. Constrained corticotropin releasing factor (CRF) agonists and antagonists with $\mathrm{i}-(\mathrm{i}+3) \mathrm{Glu}-$ Xaa-DXbb-Lys bridges. J . Med. Chem. 1998, 41, 5002-5011.

(60) Rivier, . .; Rivier, C.; Vale, W. Synthetic competitive antagonists of corticotropin releasing factor: Effect on ACTH secretion in the rat. Science 1984, 224, 889-891.

(61) Vale, W.; Vaughan, J.: Yamamoto, G.; Bruhn, T.; Douglas, C. Dalton, D.; Rivier, C.; Rivier, J . Assay of corticotropin releasing factor. In Methods in Enzymology: Neuroendocrine Peptides; Conn, P. M., Eds.; Academic Press: New York, 1983; Vol. 103, pp 565-577.

(62) Beyermann, M.; Fechner, K.; Furkert, J .; Krause, E.; Bienert, $M$. A single-point slight alteration set as a tool for structureactivity relationship studies of ovine corticotropin releasing factor. J . Med. Chem. 1996, 39, 3324-3330.

(63) Rivier, J .; Rivier, C.; Galyean, R.; Miranda, A.; Miller, C.; Craig, A. G.; Yamamoto, G.; Brown, M.; Vale, W. Single point Dsubstituted corticotropin releasing factor anal ogues: Effects on potency and physicochemical characteristics. J. Med. Chem. 1993, 36, 2851-2859.

(64) Hernandez, J .-F .; Kornreich, W.; Rivier, C.; Miranda, A.; Yamamoto, G.; Andrews, J .; Taché, Y.; Vale, W.; Rivier, J . Synthesis and relative potencies of new constrained CRF antagonists. J . Med. Chem. 1993, 36, 2860-2867.

(65) Felix, A. M.; Wang, C.-T.; Heimer, E. P.; Fournier, A. Applications of BOP reagent in solid-phase synthesis. II. Solid-phase side-chain to side-chain cyclizations using BOP reagent. Int. J. Pept. Prot. Res. 1988, 31, 231-238.

(66) Miller, C.; Rivier, J . Analysis of synthetic peptides by capillary zone electrophoresis in organic/aqueous buffers. J . Pept. Res. 1998, 51, 444-451.

(67) Rivier, C.; Shen, G. H. In the rat, endogenous nitric oxide modulates the response of the hypothalamic-pituitary-adrenal axis to interleukin-1 $\beta$, vasopressin and oxytocin. J . Neurosci. 1994, 14, 1985-1993.

J M9902133 